\title{
Influence of Political Events, Inflation, and the Exchange Rate on Credit Growth of Commercial Banks
}

\author{
Yulius Yuwono Saputra ${ }^{1}$, Sudjono $^{2}$, Ahmad Badawi Saluy $^{3}$ \\ \{saputra.yuwono@gmail.com ${ }^{1}$, sudjono@mercubuana.ac.id ${ }^{2}$, ahmad.badawi@mercubuana.ac.id $^{3}$ \}
}

Mercu Buana University, Jakarta, Indonesia ${ }^{123}$

\begin{abstract}
This study aims to analyses the influence of election political events, inflation and the exchange rate on credit growth of Commercial Banks with Loan to Deposit Ratio (LDR) as a moderating variable. The research data is secondary data, quantitative, panel data obtained from observations for five years, from May 2014 to June 2019. The study population is all Commercial Banks listed on the Indonesia Stock Exchange and has never been delisted from May 2014 to June 2019 totaled 31 Conventional Commercial Banks, the research sample was 23 banks using the purposive sampling method. Data analysis using panel data regression Least Square Dummy Variable with 1426 observations. The results of the study found that there was a positive and non-significant effect of election political events on credit growth, a positive and significant effect of inflation on credit growth, and a negative and nonsignificant effect of the rupiah exchange rate on credit growth. Simultaneous testing, there is a significant influence of the three independent variables on the loan growth dependent variable, while testing by including the LDR moderating variable, there is a positive and non-significant effect of the LDR on the influence of the independent variables on the dependent variable.
\end{abstract}

Keywords: Political Events, Election, Inflation, Exchange Rate, LDR

\section{Introduction}

The successful implementation of the 2019 elections won by Ir. H. Joko Widodo and K.H. Ma'ruf Amin as a pair of President and Vice President obtain appreciation as the election with the highest participation during Indonesian history of election in the reformation era - reached 81 percent participation rate. The voter participation rate which even surpassed the national target of 77.5 percent shows the level of enthusiasm of the people and reflects an increasingly mature democratic life. The success of Ir. H. Joko Widodo as an incumbent in the second period cannot be separated from political and economic achievements and the image of a "clean" government that was managed to be built during the first period of 2014-2019. To present effective, efficient, integrity, professional, and neutral public services, the prerequisites of free from collusion, corruption, and nepotism are needed [1].

The 2014 and 2019 Indonesian Presidential Elections are the 3rd and 4th elections in Indonesia history which provide an opportunity for the Indonesian people to elect their President and Vice President directly. The legal basis for the implementation of the 2014 
elections is Law Number 8 of 2012 concerning the Election of Members of the DPR, DPD, and DPRD, and Law Number 42 of 2008 concerning Elections of President and Vice President. In the 2014 Election, the Presidential and Legislative Elections were held separately while in the 2019 Elections for the first time the election of the President and Legislative Members was held simultaneously based on the provisions of Law Number 7 of 2017 concerning General Elections. From 2014 through 2019, there are at least 6 (six) prominent national political events, they were (1) Legislative Elections, April 2014 (2) Presidential Elections, July 2014 (3) Simultaneous Local Elections, December 2015 (4) Simultaneous Local Elections, February 2017 (5) Simultaneous Local Elections, June 2018, and (6) Legislative and Presidential Elections, April 2019. Several national agendas around the implementation of these elections often raise the tension and dynamics of democratic life and are believed to influence the economy.

From a democracy point of view, the level of democracy in Indonesia in the 2014-2019 period is categorized as moderate if measured from the figures of the Indonesian Democracy Index (IDI). IDI is a composite index consisting of 3 (three) main aspects, namely: (1) aspects of civil liberties, (2) aspects of political rights and, (3) aspects of democratic institutions. Classification of the level of democracy is grouped into three categories, namely "good" (index> 80), "moderate" (index 60-80), and "bad" (index $<60$ ). The IDI score since the start of measurement in 2009 is still around the 60-80 or medium category. The influence of democracy on economic growth usually focuses on the possible causal effects of the degree of contemporary democracy on the performance of economic growth in a country [2]. The results of the study of Acemoglu et al., (2019) concluded that democracy had a positive and significant effect on the growth of Gross Domestic Product (GDP) per capita [3]. In contrast to Bhagwati (2002) countries with democratic systems will be vulnerable to social conflicts and uncertainties that harm investment and economic growth [4]. Research by Aisen and Veiga (2013) shows that political instability has a negative and significant impact on a country's economic growth because it has an impact on decreasing the level of productivity [5].

Liew and Rowland (2016) found that political uncertainty during the election had a significant negative effect on stock market returns [6]. Cole (2009) found that there was an increase in agricultural credit by 5-10 percent during the election period in state-owned banks in India that were not associated with an increase in agricultural production [7]. The study of Jackowicz (2011) found empirical evidence supporting the theory of political benefits, which found an increase in bank credit growth during the election period, although there was a special note that state-owned banks had a significantly lower net interest income ratio during the election years [8]. This result is different from Maier (2002) who found that central banks in the US, Japan, and Germany were not affected by election events [9].

The condition of democratic maturity is related to whether or not an election political event can affect the economy. Barro's research (1994) revealed that there is a positive influence on economic growth on the developing level of democracy while a mature level of democracy harms growth. Democracy promotes growth at an immature level of development with a low level of political freedom but instead suppresses growth when a moderate level of freedom has been achieved [10]. In Indonesia, Moricz and Sjoholm's (2014) research on the effect of the election was found that the election did not significantly influence economic growth [11]. Different results by Sariartha (2012) which states that elections have a significant positive effect on credit growth [12].

Banks play the role of intermediaries that connects units that have excess funds in the financial market with underfunding units. The bank accepts deposits from customers who 
have excess funds and uses these funds to provide loans toward other customers. Credit distribution can be described as the heart of the banking business [13]. The ability to extend credit by banks is influenced by various things that can be viewed from an internal and external perspective. From the internal side, lending is influenced by the ability of banks to raise public funds or Third-Party Funds (DPK) and setting interest rates for savings, current accounts, deposits, and loans. Bank lending is also influenced by external factors, namely: economic conditions, government regulations, and others [14]. During 2014-2019, banking business trends in Indonesia showed a less encouraging and downward trend. However, the downward trend in Indonesia's banking credit growth is inversely proportional to the fluctuations of the Commercial Bank LDR in the period 2014-2019.

Not only internal factors such as LDR, but bank performance is also influenced by external factors that are often identified as macroeconomic factors that aggregate affect the financial performance and value of a company. If what is learned in microeconomics is limited to the influence between economic variables in a small scope of the company, then macroeconomics studies and observes overall and comprehensive economic performance [15]. Macroeconomic determinants that are often the main issue in the political economy are the issue of price stability or inflation control. A low and stable inflation rate will stimulate economic growth, on the other hand, a high inflation rate will harm the economy which can further disrupt political stability. Negative impacts include reducing the excitement of investment, not economic growth, worsening income distribution, and reducing the purchasing power of the people [16]. The inflation rate in the 2014-2019 period was relatively successfully controlled by the government, reflecting the condition of national economic stability.

One of the credit risk factors is exchange rate risk, which is defined as the risk due to the comparison of the value of a country's currency with other countries. The weakening of a country's exchange rate against foreign currencies causes an increase in the cost of imported raw materials for production and also increases interest rates. A weaker exchange rate will affect the decline in the value of stock prices in the capital market because investors do not believe in economic conditions. Declining share prices make investors withdraw funds in the country, resulting in capital outflows. Investment in the country feels scarce which results in decreased credit [17]. However, the fluctuations of the exchange rate in the period 20142019 shows a very dynamic condition following the evolving market trends.

\subsection{Literature review}

Discussion of credits can be explained using credit theories of money or debt theories of money, a theory of monetary economics about the relationship between credit and money. The supporters of this theory such as Alfred Mitchell-Innes emphasize that money and credit (debts) are the same, seen from a different point of view. With the development of human civilization, the use of cash (paper and coins) has been replaced with credit money issued by the bank so that the bank plays an important role in the process of money creation through credit distribution activities. According to Rivai (2005), credit is the delivery of goods, services, or money from one party, namely a creditor or lender based on trust to another party, namely the debtor or debtor with the promise to pay from the credit recipient to the creditor on the date that has been agreed by both parties [18].

According to Surbakti (2010) the definition of politics is the interaction between the government and the community in the framework of the process of making and implementing binding decisions about the common good of people who live in a certain area [19]. To allocate resources among the community groups, power is needed that is held by 
political authorities. By using existing resources in a country, leaders who have power have the right to determine what types of goods and services are produced (for example, focus on industry or services) and how the methods used in producing goods/services are produced (labor-intensive vs. capital intensive).

Inflation is an increase in the prices of goods that are general and continuous [20]. Meanwhile, according to Latumaerissa (2011) a brief definition of inflation is the tendency of prices to increase continuously [21]. An indicator often used to measure inflation is the Consumer Price Index (CPI). Changes in the CPI from time to time show the price movements of packages of goods and services consumed by the public. The exchange rate of a country's currency against a foreign currency is called the exchange rate is the price of a currency against other currencies [22]. Exchange rates play a very important role in translating prices from various countries into the same language [23].

\section{Research Method}

This research is a type of quantitative research with associative methods. In this research, the associative method is used to test the effect of election political events, inflation, and the exchange rate on the credit growth of Commercial Bank in 2014-2019. The data used in this study are quantitative data that is statistical data in the form of numbers, both directly extracted from research principles and the results of qualitative data processing to be quantitative. The study population is all Commercial Banks listed on the Indonesia Stock Exchange and has never been delisted from May 2014 to June 2019 totaled 31 Commercial Banks, the research sample was 23 banks using the purposive sampling method. Data analysis using panel data regression Least Square Dummy Variable with 1426 observations.

\section{Results and Discussion}

To determine the most appropriate panel data regression model, the Chow test and Hausman test were used with the results chosen as the fixed-effect method. Chow test for this model has a probability value of $\mathrm{F}$ and Chi-square smaller than alpha $0.0000<0.05$ so that the model that matches the following test results is the fixed effect and the common effect is rejected. Hausman test results indicate that the p-value is greater than alpha $1,0000>$ 0.5 where according to the calculation of the $\mathrm{H}_{0}$ or random effect method is accepted. But there is information that the cross-section test variance is invalid. Hausman statistic set to zero. This means that the best estimate of the random effect variant is zero or there is no random effect, so it can be concluded that the fixed effect method is better than the random effect.

The classic assumption test is the multicollinearity test to determine whether there is a correlation between the independent variables in the regression model and the heteroscedasticity test to test whether there is an inequality of variance from residuals. Multicollinearity testing is done by looking at the correlation matrix of the independent variables, if the correlation coefficient is less than 0.80 then there is no multicollinearity. The results of the multicollinearity test variable X1 has a correlation coefficient of $-0.188<0.80$ to $\mathrm{X} 2$ and $-0.135<0.80$ to $\mathrm{X} 3$. Variable $\mathrm{X} 2$ has a correlation coefficient of $-0.188<0.80$ to $\mathrm{X} 1$ and $-0.587<0.80$ to X3. Variable X3 has a correlation coefficient of $-0.135<0.80$ to X1 
and $-0.587<0.80$ to $\mathrm{X} 2$. From the results of the multicollinearity test, it was concluded that there were no symptoms of multicollinearity because of the correlation coefficient $<0.80$.

Heteroscedasticity test through the Heteroskedasticity LR Test Cross-section Panel is seen by comparing the results of the sum square residuals in Weighted Statistics if it is smaller than the sum square residual Unweighted Statistics, then heteroscedasticity occurs. Heteroscedasticity test results of the sum square residual value in Weighted Statistics 2023464. not smaller than the sum square residual Unweighted Statistics, so that $\mathrm{H}_{0}$ is accepted or it can be concluded that there are no symptoms of heteroscedasticity.

To prove the hypothesis in this study used panel data regression using the fixed-effect method or Least Square Dummy Variable (LSDV) technique, and the panel data regression equation is obtained as follows:

$$
\mathrm{Y}=-2,494957+1,352262 \mathrm{X} 1+4,056483 \mathrm{X} 2-0,070445 \mathrm{X} 3
$$

From the regression equation, it can be concluded that the value of the constant coefficient of -2.494957 means that if the variables X1, X2, X3 are zero then the amount of credit growth is -2.449957 assuming the other variables remain.

a. The regression coefficient value of variable $\mathrm{X} 1$ is positive that is 1.352262 meaning that each $1 \%$ increase in the political events variable $(\mathrm{PE})$ is predicted to increase credit growth by 1.352262 assuming the other variables are fixed.

b. The regression coefficient value of variable X2 has a positive value of 4.056483 meaning that each $1 \%$ increase in the inflation variable (INF) is predicted to increase credit growth by 4.056483 assuming the other variables remain constant.

c. The regression coefficient value of variable X3 is negative, which is -0.0704445 meaning that each $1 \%$ increase in the variable exchange rate of the rupiah against the US dollar (KURS) is predicted to reduce credit growth by -0.0704445 assuming the other variables are fixed.

To find out the magnitude of the effect of partially and simultaneously the independent variable on the dependent variable t-test and $\mathrm{F}$ test were used. A partial test or t-test was used to determine the effect of each independent variable in explaining the variation of the dependent variable. This test is done by looking at the p-value probability, if the $p$-value probability $<\alpha 0.05$ then $\mathrm{H}_{0}$ is rejected, which means the variable has a significant effect. Conversely, if the p-value probability $>\alpha 0.05$ then $\mathrm{H}_{0}$ is accepted, it means that the variable does not have a significant effect.

Based on the results of the regression analysis obtained t-test results, as follows:

a. Variable $\mathrm{X} 1$ to $\mathrm{Y}$ variable p-value $0.4782>\alpha 0.05$. This $\mathrm{H}_{01}$ is accepted and $\mathrm{H}_{1}$ is rejected, which means that political events have a non-significant effect on credit growth.

b. Variable $\mathrm{X} 2$ to $\mathrm{Y}$ variable p-value $0,0000<\alpha 0,05$. This $\mathrm{H}_{02}$ is rejected and $\mathrm{H}_{2}$ is accepted, which means that inflation has a significant effect on credit growth.

c. Variable $\mathrm{X} 3$ to $\mathrm{Y}$ variable $\mathrm{p}$-value $0.6838>\alpha 0.05$. This $\mathrm{H}_{03}$ is accepted and $\mathrm{H}_{3}$ is rejected, which means that the exchange rate has a non-significant effect on credit growth.

The F test is used to see whether the independent variable simultaneously influences the dependent variable. This test can be done by looking at the p-value probability. If the p-value probability $<\alpha \quad 0.05, \mathrm{H}_{4}$ is accepted, which means that the independent variable simultaneously has a significant effect on the dependent variable. Conversely, if the p-value probability $>\quad \alpha \quad 0.05$ then $\mathrm{H}_{04}$ is accepted, it means that the independent variable simultaneously does not have a significant effect on the dependent variable. Based on the $\mathrm{F}$ test results obtained p-value of $0.0000<\alpha 0.05$ then $\mathrm{H}_{04}$ is rejected and $\mathrm{H}_{4}$ is accepted 
meaning that the independent variables simultaneously have a significant effect on the dependent variable. Looking at the comparison of the value of $\mathrm{R}^{2}$ in the regression equation after the moderation variable is entered that is $0.236267>0.236220$ there is a positive influence of the Loan to Deposit Ratio (LDR) moderation variable, but the increase in $\mathrm{R}^{2}$ is only 0.000047 or $0.0047 \%$ does not meet the significance level of 0.05 or $5 \%$ so $\mathrm{H}_{05}$ is accepted and $\mathrm{H}_{5}$ is rejected. It can be concluded that the LDR does not significantly affect the effect of election political events (PE), inflation (INF), and the exchange rate (KURS) on credit growth (CR).

The discussion of this study explains that the findings or results of the study are as follows:

a. The results of the study found that the election political events have a positive but nonsignificant effect on credit growth. This finding is in line with the political benefit theory proposed by Barro (1996) that democracy has a positive effect on economic growth, especially at the level of democracy that is not yet mature and is still developing as conditions in Indonesia. The results of the study show that election political events have non-significant effect on credit growth, in line with the research results of Dicko (2016) [24], Baum and Lake (2003) [25], Maier (2002), and Moricz and Sjoholm (2014). Contrary to the results of the study by Cai (2017) [26], Pinho and Madeleno (2009) [27], Knutsen (2018) [28], Acemoglu (2019), Cole (2009), Jackowicz (2011), and Sariartha (2012).

b. Based on the results of study that shows that election political events have a positive but non-significant effect on credit growth, banking business actors and investors should not have to worry too much about the impact of political instability before, during, and after the General Election. Tightening access to credit due to concerns over the impact of the General Election will actually harm national economic development. According to Beck (2000) the economic growth of a country is highly dependent on the development of the financial sector, in particular the relaxation of access to finance or credit [29].

c. Furthermore, the study found that inflation had a significantly positive effect on credit growth. The results of the multiple regression equation show that each $1 \%$ increase in the inflation variable is predicted to increase credit growth by $4.06 \%$ assuming the other variables are fixed. The significance test results show that the inflation variable significantly influences the credit growth variable based on the p-value of the inflation variable to the credit growth variable of $0.0000<\alpha 0.05$.

d. The findings of this study indicate that the rupiah exchange rate variable has a negative and non-significant effect on credit growth. The results of the multiple regression equation show that each $1 \%$ increase in the exchange rate variable is predicted to decrease credit growth by $-0.07 \%$ assuming the other variables are fixed. Significance testing results show that the effect of the exchange rate variable on the credit growth variable is non-significant based on the p-value of the exchange rate variable on the variable credit growth of $0.6838>\alpha 0.05$.

e. The results also show that the variables of election political events, inflation, and the exchange rate together significantly influence credit growth. The results of significance testing through the simultaneous test $(F$ test) obtained a p-value of $0.0000<\alpha 0.05$ meaning that the independent variable simultaneously had a significant effect on the dependent variable. The contribution of the influence of political events, inflation, and the rupiah exchange rate together to credit growth is shown by the coefficient of determination of 0.236 . This means that $23.6 \%$ of credit growth is influenced by the variables of political events (PE), inflation (INF), and the exchange rate of the rupiah 
(KURS) while the remaining $76.4 \%$ is influenced by other factors such as capital adequacy ratio (CAR), credit problems (NPL), Bank Indonesia Interest Rates (SBBI), Gross Domestic Product (GDP), Rule of Law Index (INH), etc.

f. The results of this study found that there is a positive effect of the Loan to Deposit Ratio (LDR) as a moderating variable on the influence of political events, inflation, and the exchange rate to the credit growth as indicated by an increase in the value of $\mathrm{R}^{2}$ in the regression equation after the moderation variable has been entered in the amount of 0.000047 or $0.0047 \%$. This increase does not meet the specified significance level of 0.05 or $5 \%$ so it can be concluded that the LDR does not significantly affect the influence between political events, inflation, and the exchange rate to credit growth.

\section{Conclusion}

The results of the study found that there was a positive and non-significant effect of election political events on credit growth, a positive and significant effect of inflation on credit growth, and a negative and non-significant effect of the rupiah exchange rate on credit growth. Simultaneous testing, there is a significant influence of the three independent variables on the loan growth dependent variable, while testing by including the LDR moderating variable, there is a positive and non-significant effect of the LDR on the influence of the independent variables on the dependent variable.

\section{References}

[1] F. A. A. Badawi Saluy, Ahmad Prawira, Budi Buntaran, "The Influence of Leadership, Working Culture, and Working Environment for the Ministry of Administrative Reform and Bureaucracy,” Int. J. Bus. Econ. Aff., vol. 4, no. 5, pp. 224-234, 2019, doi: 10.24088/ijbea2019-45003.

[2] J. Gerring, P. Bond, W. T. Barndt, and C. Moreno, "Democracy and Economic Growth: A Historical Perspective,” World Polit., 2005, doi: 10.1353/wp.2006.0002.

[3] D. Acemoglu, S. Naidu, P. Restrepo, and J. Robinson, "Democracy Does Cause Growth," J. Polit. Econ., vol. 127, no. 1, pp. 47-100, 2019.

[4] J. Bhagwati, "Democracy and Development: Cruel Dilemma or Symbiotic Relationship?," Rev. Dev. Econ., vol. 6, no. 1, pp. 151-162, 2002.

[5] A. Aisen and F. J. Veiga, "How does political instability affect economic growth?," Eur. J. Polit. Econ., 2013, doi: 10.1016/j.ejpoleco.2012.11.001.

[6] V. K. Sen Liew and R. Rowland, "The effect of Malaysia general election on stock market returns," Springerplus, vol. 5, no. 1, 2016, doi: 10.1186/s40064-016-3648-5.

[7] S. Cole, "Fixing market failures or fixing elections? Agricultural credit in India," Am. Econ. J. Appl. Econ., vol. 1, no. 1, pp. 219-250, 2009, doi: 10.1257/app.1.1.219.

[8] K. Jackowicz, O. Kowalewski, and L. Koslowski, ""The Impact of Electoral Factors on Commercial Banks in CEE Countries,” Work. Pap. Univ. Pennsylvania, vol. 11-02, pp. 1-7, 2011.

[9] P. Maier, "Rhetoric and Action: What are Central Banks Doing Before Elections," Public Choice, vol. 112, pp. 235-258, 2002, doi: 10.1023/A:1019997222044.

[10] R. J. Barro, "Democracy and Growth,” J. Econ. Growth, vol. 1, no. 27, 1996.

[11] S. Moricz and F. Sjoholm, "The Effect of Elections on Economic Growth: Results from a Natural Experiment in Indonesia," IFN Work. Pap., no. May, pp. 2-52, 2014.

[12] A. Sariartha, Alfiana, and V. W. Widajatun, "Dampak Pemilu Terhadap Pertumbuhan Kredit Perbankan," Simp. Nas. Keuang. dan Perbank. Pertama, Kerjasama antara STIE Indones. 
IFMA, FEB Univ. Diponegoro, FE Univ. Negeri Jakarta, FEB Univ. Singaperbangsa, FEB Univ. Esa Unggul, STIE Perbanas Surabaya, ISEI Jaya., vol. 3, no. September, pp. 1-22, 2012.

[13] A. A. Adzis, L. E. Sheng, and J. A. Bakar, "Bank Lending Determinants : Evidence from Malaysia Commercial Banks,” J. Bank. Financ. Manag., vol. 1, no. 3, pp. 36-48, 2018.

[14] D. Retnadi, "Perilaku Penyaluran Kredit Bank," J. Kaji. Ekon., 2006.

[15] P. A. Samuelson and W. D. Nordhaus, Economics, 19th ed. 2009.

[16] A. Sutawijaya and Zulfahmi, "Pengaruh Faktor-Faktor Ekonomi Terhadap Inflasi Di Indonesia,” Organ. dan Manaj., vol. 8, pp. 85-101, 2012.

[17] M. Nurrohim, "Analisis Kausalitas Volatilitas Nilai Tukar Mata Uang Dengan Kinerja Sektor Keuangan dan Sektor Rill,” Econ. Dev. Anal. J., vol. 2, no. 4, pp. 351-366, 2013.

[18] V. Rivai, Manajemen Sumber Daya Manusia Untuk Perusahaan : dari Teori ke Praktik, Edisi 1. Jakarta: PT. Raja Grafindo Persada, 2005.

[19] R. Surbakti, Memahami Ilmu Politik. Jakarta: Gramedia Pustaka Utama, 2010.

[20] S. Sukirno, Makro Ekonomi Teori Pengantar, Edisi 3. Jakarta: Rajawali Pers, 2011.

[21] J. R. Latumaerissa, Bank dan Lembaga Keuangan Lain. Jakarta: Salemba Empat, 2011.

[22] Salvatore, Ekonomi Internasional, 9th ed. Jakarta: Erlangga, 2014.

[23] P. R. Krugman and M. Obstfeld, Ekonomi Internasional Teori dan Kebijakan. Jakarta: PAU FE UI dan Harper Collins Publishers, 2005.

[24] S. Dicko, "The Impact of Political Connections on the Performance and Solvency of Canadian Financial Institutions," Int. J. Econ. Financ., vol. 8, no. 11, p. 1, 2016, doi: 10.5539/ijef.v8n11p1.

[25] M. A. Baum and D. A. Lake, "The political economy of growth: Democracy and human capital," Am. J. Pol. Sci., vol. 47, no. 2, pp. 333-347, 2003, doi: 10.1111/1540-5907.00023.

[26] W. Cai, F. Xu, and C. Zeng, "Does political pressure matter in bank lending? Evidence from China," Financ. Mark. Institutions Instruments, 2017, doi: 10.1111/fmii.12089.

[27] C. Pinho and M. Madaleno, "Political regimes and economic growth," Rev. Enfoques J., vol. 7, no. No 11, pp. 471-490, 2009, doi: 10.1257/jep.7.3.51.

[28] C. H. Knutsen et al., "Economic development and democracy: An electoral connection," Eur. J. Polit. Res., pp. 292-314, 2018, doi: doi: 10.1111/1475-6765.12282.

[29] T. Beck, A. Demirguc-Kunt, R. Levine, and V. Maksimovic, "Financial structure and economic development: Firm, industry, and country evidence," Policy Res. Work. Pap. 2423, Washingt. World Bank, pp. 189-241, 2000. 